Article

\title{
Oral Application of T4 Phage Induces Weak Antibody Production in the Gut and in the Blood
}

\section{Joanna Majewska, Weronika Beta, Dorota Lecion, Katarzyna Hodyra-Stefaniak, Anna Kłopot, Zuzanna Kaźmierczak, Paulina Miernikiewicz, Agnieszka Piotrowicz, Jarosław Ciekot, Barbara Owczarek, Agnieszka Kopciuch, Karolina Wojtyna, Marek Harhala, Mateusz Mąkosa and Krystyna Dąbrowska *}

Institute of Immunology and Experimental Therapy, Polish Academy of Sciences, ul. R. Weigla 12, 53-114 Wrocław, Poland; E-Mails: joanna.majewska@iitd.pan.wroc.pl (J.M.); weronika.beta@iitd.pan.wroc.pl (W.B.); lecion@iitd.pan.wroc.pl (D.L.); katarzyna.hodyra@iitd.pan.wroc.pl (K.H.-S.); anna.klopot@iitd.pan.wroc.pl (A.K.); zuzanna.kazmierczak@iitd.pan.wroc.pl (Z.K.); pola@iitd.pan.wroc.pl (P.M.); agnieszka.piotrowicz@gmail.com (A.P.); jaroslaw.ciekot@iitd.pan.wroc.pl (J.C.); owczarek@iitd.pan.wroc.pl (B.O.); kopciuch@iitd.pan.wroc.pl (A.K.); karolina.wojtyna@gmail.com (K.W.); marek.harhala@gmail.com (M.H.); mateusz.makosa@iitd.pan.wroc.pl (M.M.)

* Author to whom correspondence should be addressed: E-Mail: dabrok@iitd.pan.wroc.pl; Tel.: +48-71-3371-172 (ext. 316).

Academic Editors: Abram Aertsen and Rob Lavigne

Received: 1 May 2015 / Accepted: 30 July 2015 / Published: 20 August 2015

\begin{abstract}
A specific humoral response to bacteriophages may follow phage application for medical purposes, and it may further determine the success or failure of the approach itself. We present a long-term study of antibody induction in mice by T4 phage applied per os: 100 days of phage treatment followed by 112 days without the phage, and subsequent second application of phage up to day 240. Serum and gut antibodies (IgM, IgG, secretory $\operatorname{IgA}$ ) were analyzed in relation to microbiological status of the animals. T4 phage applied orally induced anti-phage antibodies when the exposure was long enough (IgG day 36, IgA day 79); the effect was related to high dosage. Termination of phage treatment resulted in a decrease of IgA again to insignificant levels. Second administration of phage induces secretory IgA sooner than that induced by the first administrations. Increased $\operatorname{IgA}$ level antagonized gut transit of active phage. Phage resistant E. coli dominated gut flora very late, on day 92.
\end{abstract}


Thus, the immunological response emerges as a major factor determining phage survival in the gut. Phage proteins Hoc and gp12 were identified as highly immunogenic. A low response to exemplary foreign antigens (from Ebola virus) presented on Hoc was observed, which suggests that phage platforms can be used in oral vaccine design.

Keywords: T4 phage; EBOV; Ebola virus; oral administration; vaccine; phage display; capsid proteins; antibodies; phage resistance

\section{Introduction}

Bacteriophages deliver a few important medical solutions. One of them is antibacterial therapy, which makes use of the natural ability of bacteriophages to kill bacteria. Currently, we are observing renewed interest in phage therapy as a promising alternative to antibiotics, mostly due to the problem of antibiotic resistance in bacteria. This inspires both recapitulation of previous experience and testing for an up-to-date methodology and approach [1-7]. Special regard is given to various aspects of phage interactions with organisms of treated individuals, since these interactions determine safety issues, phage pharmacokinetics, bioavailability and resulting outcomes of antibacterial treatment.

The other popular phage solution is the technological approach to phages as nanocarriers that are able to deliver biologically active elements. Nanocarriers may deliver various kinds of drugs, but they can also constitute a platform that allows for exposure of selected antigens. Such bacteriophage-based platforms are proposed as a new generation of safe (non-pathogenic) and effective vaccines. T4 phage capsid has been experimentally used to expose antigens of difficult pathogens, e.g., Neisseria meningitidis [8], anthrax [9,10] and HIV [11,12].

All medical applications of bacteriophages, including antibacterial therapy, vaccines and others, share a common feature: phages make direct contact with the mammalian organism and thus challenge the mammalian immunological system. One of the major consequences is a humoral response to a phage [13-15]. The humoral response, however, does not follow a simple schema of induction. It appears to depend on the route of phage administration and on individual features of a phage. It also depends on the dose and application schedule and possibly on other features, not yet specified [15-18]. As a consequence, it is not easy to draw a general conclusion about the effects that anti-phage antibodies have on the outcomes of therapeutic use of bacteriophages. Some authors found that the effect of the humoral response can be devastating [19], but others reported that anti-phage activity of serum does not exclude a favorable result of phage therapy in humans [17]. The first safety study of T4 phage application on humans revealed no antibody induction in phage-treated volunteers at all [2]. Difficulties with joint conclusions from different studies are related to the multi-factor nature of the immune system and its interactions with potential antigens.

Probably one of the most complex systems that can be considered in terms of therapeutic phage application is the gut, with its dynamic balance of symbiotic and sometimes pathogenic bacteria, natural and possibly therapeutic bacteriophages, as well as a variety of mammalian host-related factors. New technologies for sequencing and the metagenomics approach have revealed extreme microbiological diversity of the natural gut ecosystem, including bacteriophages [20,21]. This microbial balance, and 
especially its impact on human health, has been recently reviewed by Dalmasso et al. [22]. In spite of emerging interest in the topic, little is known about the humoral response to therapeutic bacteriophages if they are applied orally, even though it is generally expected that phages present in the gut may induce specific antibodies [16,23].

Here we present a long-term study (240 days) of specific antibody induction by T4 phage applied per os in a murine model: 100 days of phage treatment followed by 112 days without the phage, and then repeated treatment with the same phage up to day 240 . The purpose of these studies was to provide immunological data useful for medical applications of bacteriophages, both those employing phages as antibacterials and those making use of phages as nanocarriers. In this work, the assessment comprised serum and gut antibodies ( $\operatorname{IgM}, \operatorname{IgG}, \operatorname{IgA}$ ) in relation to microbiological status of the animals: phage survival in gut and occurrence of phage-resistant bacteria. Immune response emerged as a major factor determining phage survival in the gut. The analysis concerned the individual impact of structural proteins on induction of the humoral response. Selected proteins were those exposed on the surface of phage head (gp23*, gp24*, Hoc, Soc) and the protein responsible for phage ability to infect bacteria (gp12). This allowed for the identification of highly immunogenic structural proteins and for further testing of the immune response to foreign antigen presented on the phage as a fusion with one of these proteins. Oligopeptides from Ebola virus served as exemplary foreign antigens that elicited immune response when displayed on T4 phage and administered per os.

\section{Results}

\subsection{Induction of Anti-T4 Phage Antibodies in Mice Treated with the Phage per os}

The long-term treatment and observation of mice took 240 days. During the first part, mice were given T4 phage in drinking water $4 \times 10^{9} \mathrm{pfu} / \mathrm{mL}$ (approx. $2 \times 10^{10}$ pfu per mouse daily) for 100 days, with no $\mathrm{pH}$-neutralizing additives. Then the phage was removed from the diet and the experiment was continued for the next 112 days. Then the mice were again given T4 phage in drinking water with no pH-neutralizing additives $4 \times 10^{9} \mathrm{pfu} / \mathrm{mL}$ (approx. $2 \times 10^{10}$ pfu per mouse daily) up to day 240 . Animals' blood serum and feces were repeatedly tested for the level of specific anti-phage antibodies, during the whole 240-day period of the experiment. Serum samples were tested for IgG and IgM, and feces were tested for IgA. Animals were also monitored for the presence of active bacteriophages in feces and for possible occurrence of phage-resistant bacteria in feces; microbiological data were merged with immunological ones (presented in Figure 1).

As shown in Figure 1, the initial two weeks of continuous treatment with the phage had no significant effect on any class of investigated antibodies. From the third to fifth week (days 15-36), a constant increase of blood serum IgG antibodies was observed; IgG level increased markedly and statistically significantly ( $p<0.001$ in comparison to control mice on day 36). Contrary to expectations, no clear increase of $\operatorname{IgM}$ was noted before the $\mathrm{IgG}$ boost, and $\mathrm{IgG}$ level did not decrease after removal of the phage from the diet (after day 100). Secretory IgA increased considerably later, i.e., approximately 7-8 weeks later than $\operatorname{IgG}$ (day 63-79). As a result, IgA reached its maximum after around two months of continuous treatment with the phage ( $p<0.01$ in comparison to control mice on day 79). Importantly, without continuous contact with the phage, secretion of specific IgA was gradually decreased, and on days 
180-213 no significant difference was observed in comparison to control mice. The second exposure to the phage (starting from day 213) resulted in faster induction of secretory IgA: it was significantly increased in feces as soon as on day 225 ( $p<0.05$ in comparison to control mice) (Figure 1$)$.

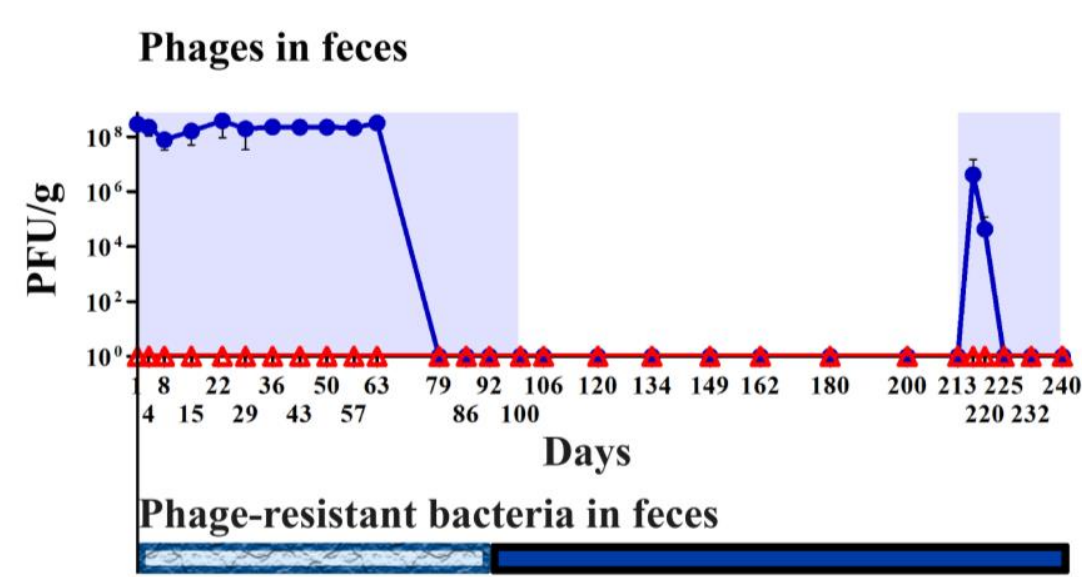

Antibodies specific to T4 phage

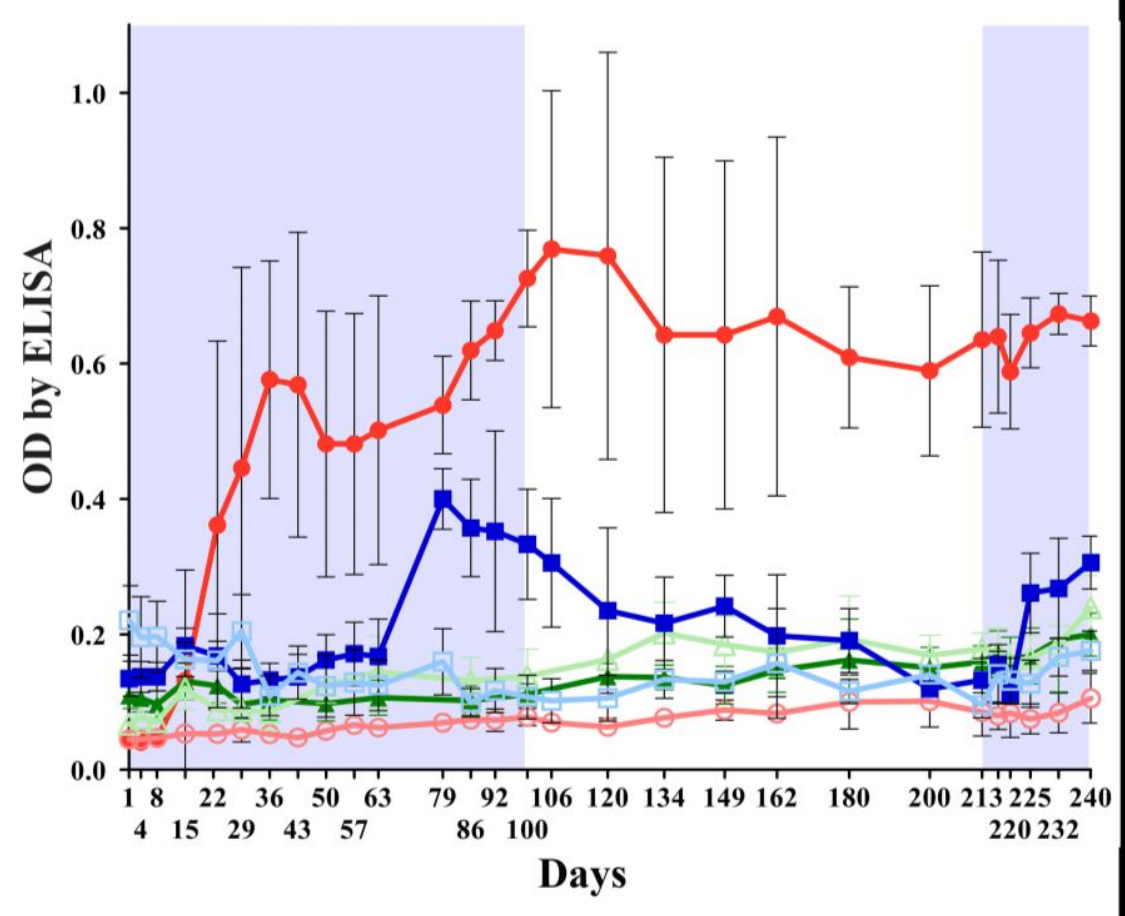

time of phage treatment

Phages in feces

T4 phage in feces control mice

T4 phage in feces T4 treated mice

Phage-resistant bacteria in feces

$<20 \%$ of phage resistant $E$. coli

口 $>80 \%$ of phage resistant $E$. coli

Antibodies specific to T4 phage

IgG

- T4 treated mice

$\ominus$ control mice

$$
\text { IgM }
$$

T4 treated mice control mice

$$
\text { IgA }
$$

T4 treated mice

$\because$ control mice

Figure 1. Bacteriophage T4 survival in the gut in correlation with increase of specific anti-phage antibodies and with emergence of phage-resistant $E$. coli. Mice $(N=7)$ were fed with T4 phage in drinking water to preclude micro-injuries that can be caused with a stomach probe and which result in false observations of phages penetrating the blood. The treatment was conducted for 100 days (days of phage treatment were marked in the figure with 
light blue). Then the phage was removed from the diet and the experiment was continued for the next 112 days. Then the phage was again administered to mice for 28 days (days of phage treatment were marked in the figure with light blue). Phage dose was $4 \times 10^{9} \mathrm{pfu} / \mathrm{mL}$ with no pH-neutralizing additives (thus making approx. $2 \times 10^{10} \mathrm{pfu} /$ mouse daily as calculated from daily water uptake per animal). Control mice received no phage in the diet and they were separated from phage-treated mice. They were examined for presence of active T4 phage and no phage activity was detected during the whole experiment. IgG and IgM levels were tested in sera (blood was collected from the tail vein under anesthesia; thus the same mice were sampled for the whole experiment), and IgA levels were tested in feces. Additionally, feces were tested for the presence of active T4 phage and for T4 phage-resistant $E$. coli.

Phages were present in feces of all phage-fed mice as long as secretory IgA levels were low. Significant increase in IgA level on day 79 resulted in complete absence of active phages in feces. Interestingly, when secretory $\operatorname{IgA}$ decreased with time, repeated dose of the phage on day 213 resulted in recovery of active phages from feces (Figure 1). Active phages were detected until phage-specific $\operatorname{IgA}$ level increased again (day 225) (Figure 1).

Phage-resistant E. coli strains dominated the gut relatively late, i.e., on day 92, shortly before the end of the phage treatment (Figure 1). From that date, they constituted $100 \%$ of bacterial colonies isolated from phage-treated mice, while in control mice only $20 \%$ of phage-resistant $E$. coli could be found in gut samples and $80 \%$ were sensitive to the phage. The prevalence of phage-resistant strains with small fluctuations was observed also during the whole time after removal of T4 from the diet and during the time of second treatment (up to day 240). No other substantial differences between phage-treated and control mice were detected in gut flora during the experiment.

In mice treated similarly with the same phage but in a lower concentration $\left(4 \times 10^{8} \mathrm{pfu} / \mathrm{mL}\right.$ - one order of magnitude lower), the immunological response was very weak. A significant increase of secretory IgA was not detected (data not shown), which was correlated with the fact that the phage was constantly present in feces $\left(10^{5} \mathrm{pfu} / \mathrm{g}\right)$; interestingly, phage-resistant $E$. coli did not dominate fecal samples even after 100 days. IgM induction was not detected in serum and the increase of serum $\operatorname{IgG}$ was meager and started later (day 30). Comparison of T4-specific IgG in murine sera on day 100 after phage treatment with $4 \times 10^{8} \mathrm{pfu} / \mathrm{mL}$ to those after treatment with $4 \times 10^{9} \mathrm{pfu} / \mathrm{mL}$ revealed 8.6 times higher immunization in the animals treated with the higher phage dose (Figure 2). These observations suggest that phage dose plays a major role in immunological outcomes of phage treatment. Serum IgG from mice treated with the phage per os for 100 days was also compared to that from mice injected with the phage s.c. (three doses, $5 \times 10^{9}$ and $5 \times 10^{9}$ and $2 \times 10^{9}$ pfu/mouse). Injection, which typically results in a very effective delivery of phages to circulation [24], resulted in 5.5 higher immunization in comparison to the higher dose applied per os (Figure 2). 


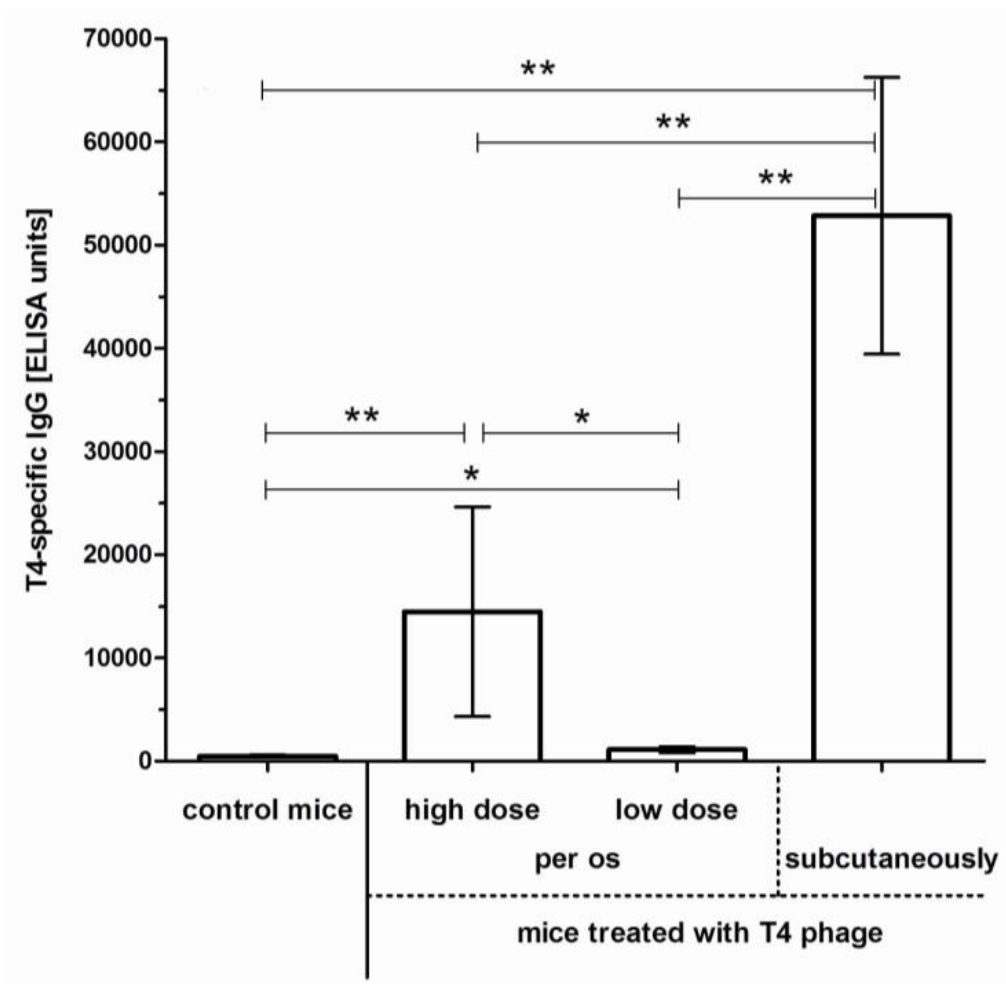

Figure 2. Intensity of anti-T4 phage IgG induction in mice treated with the phage per os and subcutaneously. Mice ( $N=6$ or 7 ) were fed with T4 phage in drinking water for 100 days, with no $\mathrm{pH}$-neutralizing additives or they were injected with the phage subcutaneously. Two doses were used for the treatment per os: $4 \times 10^{9} \mathrm{pfu} / \mathrm{mL}$ thus making approx. $2 \times 10^{10} \mathrm{pfu} / \mathrm{mouse}$ daily, as calculated from daily water uptake per animal (in the Figure: high dose) or $4 \times 10^{8} \mathrm{pfu} / \mathrm{mL}$ thus making approx. $2 \times 10^{9} \mathrm{pfu} / \mathrm{mouse}$ daily, as calculated from daily water uptake per animal (in the Figure: low dose). Subcutaneous treatment was done with three subsequent injections: $5 \times 10^{9} \mathrm{pfu} /$ mouse on day $0,5 \times 10^{9} \mathrm{pfu} /$ mouse on day $24,2 \times 10^{9} \mathrm{pfu} /$ mouse on day 48 , antibody level was tested on day 55. ELISA units were calculated for each sample according to Miura et al. [25,26]. Statistically significant differences between groups were marked with asterisks: $* p<0.05, * * p<0.01$.

\subsection{Individual Immunogenicity of Structural Proteins gp23*, gp24*, Hoc, Soc, and gp12 in Oral} Application of T4 Phage

Previous studies of T4 phage applied parenterally (i.p.) showed that phage structural proteins substantially differed in their individual immunogenicity [18]. Thus, specific response to the selected structural proteins (gp23*, gp24*, Hoc, Soc, gp12) was analyzed in samples from mice after 100 days of phage treatment per os. Antibodies specific to these proteins were analyzed by ELISA for the following classes: IgG in the blood and IgA in feces and results were expressed in ELISA units [25,26]. Proteins identified as significantly stimulating humoral response to the phage were graphically presented in Figure 3. A marked increase (in comparison to the control mice) was observed in anti-Hoc and anti-gp12 IgG (39- and 41-fold increase, respectively; $p<0.001$ ). Similarly, anti-Hoc and anti-gp12 IgA were also significantly increased, but the increase was moderate (3.8- and 3.3-fold of increase, respectively; $p<0.05$ ). Proteins Soc, gp23*, and gp24* were weakly immunogenic (Figure 3). 


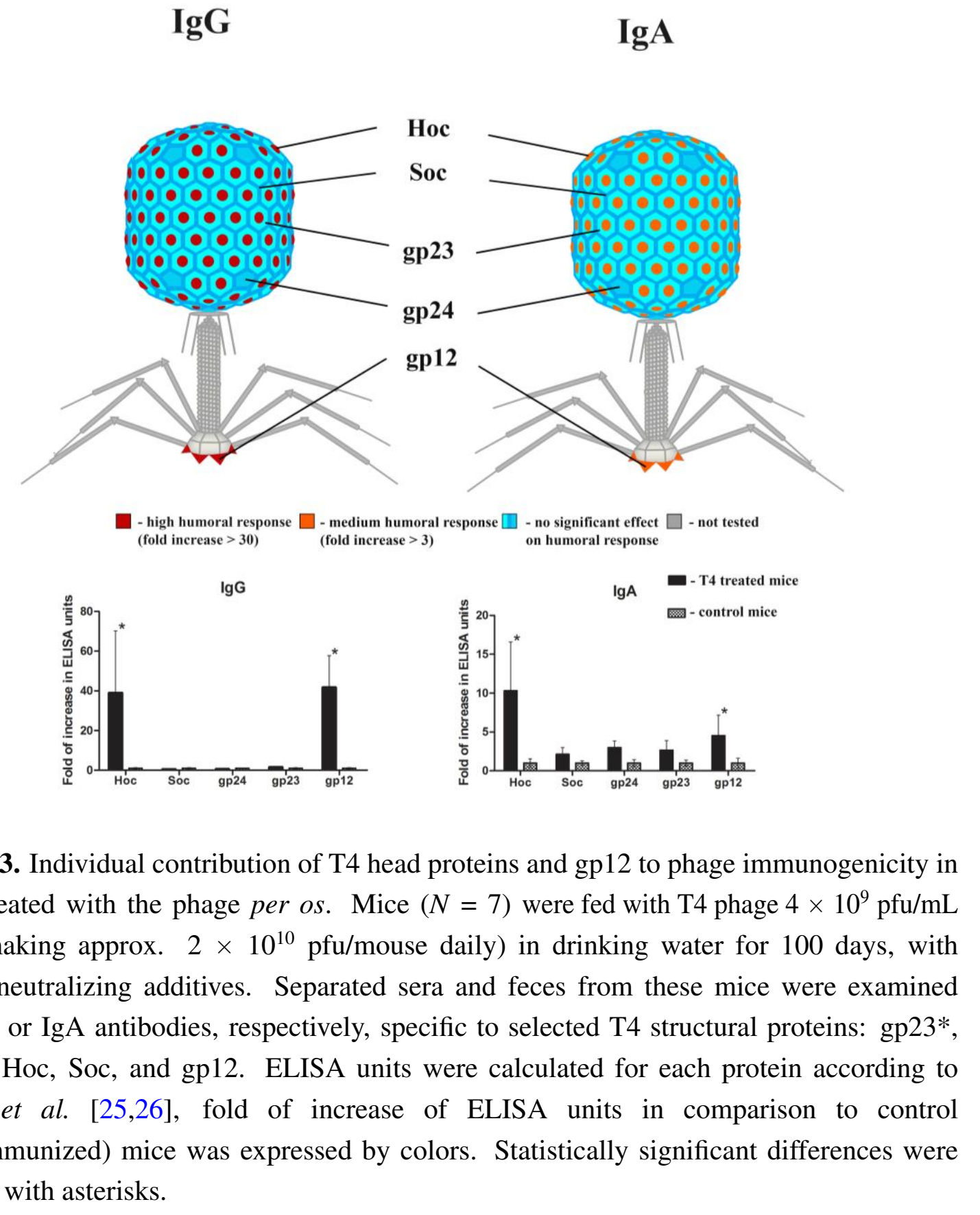

Figure 3. Individual contribution of $\mathrm{T} 4$ head proteins and gp12 to phage immunogenicity in mice treated with the phage per os. Mice $(N=7)$ were fed with T4 phage $4 \times 10^{9} \mathrm{pfu} / \mathrm{mL}$ (thus making approx. $2 \times 10^{10} \mathrm{pfu} /$ mouse daily) in drinking water for 100 days, with no $\mathrm{pH}$-neutralizing additives. Separated sera and feces from these mice were examined for IgG or IgA antibodies, respectively, specific to selected T4 structural proteins: gp23*, gp24*, Hoc, Soc, and gp12. ELISA units were calculated for each protein according to Miura et al. [25,26], fold of increase of ELISA units in comparison to control (non-immunized) mice was expressed by colors. Statistically significant differences were marked with asterisks.

\subsection{Immune Response to Foreign Antigens Presented as Fusions to Hoc Protein}

T4 phage was previously demonstrated as a phage display platform applicable for presentation of foreign antigens, and those antigens were fused i.a. to the protein Hoc. Such modified phages were injected into the mice, and they elicited production of antibodies specific to presented foreign antigens $[8-10,12]$. Therefore, we further assessed potential ability of orally applied phages to serve as vaccine platforms. As exemplary foreign antigens, we used an oligopeptide from Ebola virus (here: antigen EB1). These oligopeptides were fused to Hoc and presented on T4 capsid by the competitive phage display [27]. Purified preparations of EB1-presenting phage were added to drinking water and mice were treated similarly as in the first part of the study. Mice were tested for specific anti-EB $1 \operatorname{IgG}$ and IgA; secretory IgA specific to EB1 was detected in the gut samples (Table 1). 
Table 1. Induction of antibodies specific to the foreign antigen EB1 presented on T4 phage, after oral application of the phage. Mice were treated with the EB1 presenting phage in drinking water, control mice were not treated with phage or EB1 antigen, specific IgA and IgG levels were presented as mean ELISA units in groups (with SD); T4 phage specific antibodies served as a positive control of immunization. Statistically significant differences were marked with asterisks.

\begin{tabular}{|c|c|c|c|c|}
\hline $\begin{array}{c}\text { Class of } \\
\text { Antibodies }\end{array}$ & $\begin{array}{c}\text { Specificity of } \\
\text { Antibodies }\end{array}$ & Type of Treatment & $\begin{array}{l}\text { Immunization, } \\
\text { ELISA Units }\end{array}$ & $\begin{array}{c}\text { Statistical Significance } \\
(p<0.05)\end{array}$ \\
\hline \multirow{2}{*}{$\operatorname{IgA}$} & anti-EB1 & $\begin{array}{l}\text { T4_EB1 treatment } \\
\text { control }\end{array}$ & $\begin{array}{c}106,681( \pm 13,892) \\
30,778( \pm 10,853)\end{array}$ & $*$ \\
\hline & anti-T4 & $\begin{array}{c}\text { T4_EB1 treatment } \\
\text { control }\end{array}$ & $\begin{array}{c}175,507( \pm 61,845) \\
18,667( \pm 4628)\end{array}$ & $*$ \\
\hline \multirow{2}{*}{$\operatorname{IgG}$} & anti-EB1 & $\begin{array}{c}\text { T4_EB1 treatment } \\
\text { control }\end{array}$ & $\begin{array}{l}282( \pm 47) \\
295( \pm 29)\end{array}$ & \\
\hline & anti-T4 & $\begin{array}{c}\text { T4_EB1 treatment } \\
\text { control }\end{array}$ & $\begin{array}{c}18,047( \pm 4655) \\
557( \pm 24)\end{array}$ & $*$ \\
\hline
\end{tabular}

\section{Discussion}

A specific humoral response to bacteriophages may follow phage application for medical purposes and it may further determine the success or failure of the approach itself. Therefore, we investigated specific antibodies induced by a model phage together with microbiological characteristics. Our studies of long-term phage treatment clearly show that phages applied per os are able to induce a humoral response. This response may emerge in situ, by secretion of specific IgA to the gut lumen, but also in the blood serum as specific IgG (Figure 1). Intensity of this response and the time necessary for its induction depend on the exposure to phage antigens, which is related to phage dose (Figure 2). Specific IgA secretion turned out to be a limiting factor for phage activity in the gut. Its significant increase correlated with the lack of phages detected in feces, while an increase of serum IgG did not significantly affect gastrointestinal transit of active phages. Phages were present in murine feces as long as secretory IgA levels were low. When IgA level increased on day 79, no active phages were detected in feces. Interestingly, secretory IgA decreased with time (on day 213 it was similar to its initial levels) and this decrease allowed for the successful passage of active phages through the gut for approximately one week. Active phages were detected until phage-specific IgA level increased again on day 225 (Figure 1).

Induction of serum IgG suggests that phage can be translocated from the gut lumen to the circulation. "Gut phage" ability to induce an immunological response in humans and in animals, or even their ability to penetrate to the blood and internal organs, has never been clearly defined. One may find both examples of phages that did [28-31] and those that did not [2,32] penetrate after gastric delivery. Some studies have shown that phage translocation was rather weak [33], but it was postulated to impact systemic immune reactions [16,34]. We detected a small titer of the phage $\left(10^{3} \mathrm{pfu} / \mathrm{mL}\right)$ in murine blood after application of the higher phage dose $\left(4 \times 10^{9}\right.$ pfu per $\mathrm{mL}$ of drinking water) (data not shown). The lower phage dose $\left(4 \times 10^{9} \mathrm{pfu} / \mathrm{mL}\right)$ did not allow for detectable translocation of the phage to the circulation (the detection limit was $200 \mathrm{pfu} / \mathrm{mL}$ of blood, as calculated from blood volume that was tested; this volume was limited due to ethical reasons). These observations show that even very low amounts of 
phage that reach the circulation can induce a long-lasting secondary response of the immune system, when the exposure is long enough.

For phage therapy purposes, it would be useful to assess general immunogenicity of the phage applied per os as "high" or "low". This requires calculation of comparable phage doses between mice and humans. Pharmacokinetic scaling of bacteriophage doses from mice to humans is not easy, since typical calculation schema have been developed for much smaller agents of generally different characteristics (e.g., small proteins) [35]. Thus, to estimate adequate phage doses in humans we used the simplification of volumes as proportional to weight across species. With such a calculation, the higher dose of T4 phage used in this study for mice, $2 \times 10^{10}$ pfu per mouse daily, equals $7 \times 10^{13}$ pfu per human patient daily. Such high doses are, in the least, unusual in therapeutic approaches in humans; according to Sulakvelidze et al. [36], during the 20th century, phages were administered to humans orally, in tablet or liquid formulations containing $10^{5}$ to $10^{11} \mathrm{pfu} /$ dose. Phage titers used for experimental therapy at the Institute of Immunology and Experimental Therapy (IIET), Phage Therapy Unit (Wrocław, Poland), in the years 2008-2010, ranged between $3 \times 10^{7}$ and $6 \times 10^{10}$ pfu per human patient daily [4]. Human volunteers in phage T4 safety tests reported by Bruttin and Brussow [2] received a total of $9 \times 10^{7}$ pfu, and no specific antibodies were detected after that. In our studies, the lower, much less immunogenic dose applied to mice equals $7 \times 10^{12}$ pfu per human patient daily, which is still much. Taking into account how persistent treatment was necessary to achieve a marked immunological response (two weeks of a higher dose to start the increase of $\mathrm{IgG}$ and more than two months to induce $\operatorname{Ig} \mathrm{A}$ ), we conclude that $\mathrm{T} 4$ phage applied per os was weakly immunogenic.

Interestingly, these were immunological factors that turned out to limit phage viability in the gut, with no significant role of phage resistance in bacteria. Interestingly, among E. coli clones isolated from non-treated mice, as much as $80 \%$ were sensitive to T4 phage, which can be considered as a high fraction. Phage resistant bacterial strains dominated gut E. coli relatively late (day 92), and they did not determine the lack of viable phages in feces (Figure 1). This is in accordance with observations of Maura and Debarbieux [37], who reported that a phage present in the murine gut for 30 days did not give rise to domination of relevant phage-resistant bacteria. Possibly, the "arms race" between phages and bacteria is much more rapid in laboratory liquid monocultures than in the complex environment of the mammalian gut. Prolonged selection pressure necessary to select phage-resistant bacteria suggests that, at least in this model, phage propagation on commensal gut flora plays a marginal role. This is in line with the observations of Weiss et al. [38], who found it questionable whether T4 can effectively propagate on gut bacteria.

Structural elements of the phage capsid may differ in their individual immunogenicity [18]. Here we observed that humoral response to the phage was strongly stimulated by Hoc protein and gp12 (both IgG in the blood and IgA in the gut), while gp23*, gp24*, and Soc induced low response. High-level immunization against gp12 may strongly impact phage antibacterial activity, since gp12 plays a key role during phage infection of bacteria. A possible direction for future studies might be revealing factors promoting humoral response to gp12, which could be further applied for optimal design of phage use in humans and animals. The Hoc protein, in turn, was shown as an effective fusion protein in phage display of foreign antigens as presented by the group of V. Rao [8-10,12]. Here we proposed further study in the field; this study was comprised of a long duration of monitoring of the immune reaction and 
its dependency on dose, application schedule and route of administration. Recently, bacteriophages have also been employed for DNA vaccine technologies (BigDNA's technology) that combined phages and DNA vaccines $[39,40]$. Thus, the high immunogenicity of Hoc may be of an advantage in developing vaccines. We found that foreign antigens displayed on the T4 phage as the Hoc-fusion can induce specific secretory $\operatorname{IgA}$. We propose this result as an example of T4 phage use as an oral vaccine, and we hypothesize that further optimization of particular antigens and their arrangement on the capsid may deliver new solutions for vaccine development.

\section{Materials and Methods}

\subsection{Bacteriophages}

T4 phage was purchased from American Type Culture Collection (ATCC) (Rockville, MD, USA). The phage was cultured on an Escherichia coli B host obtained from the Collection of Microorganisms at the IIET, culture medium was LB-Broth high salt (Sigma-Aldrich, Poznan, Poland). The culture was conducted $8-10 \mathrm{~h}$ in $37{ }^{\circ} \mathrm{C}$. Phage lysates were purified by filtration through polysulfone membrane filters $0.22 \mu \mathrm{m}$ (Merck Millipore, Billerica, MA, USA) and added to drinking water for mice or used for further purification before they were applied as bottom antigens for ELISA. Purified phage preparations were obtained by two steps of chromatography: gel filtration on Sepharose 4B (Sigma-Aldrich, Poznań, Poland) followed by dialysis against PBS on 1000 kDa-pore membranes and LPS-affinity chromatography EndoTrap Blue according to the manufacturer's instructions (Hyglos GmbH, Bernried, Germany). LPS removal was done by three successive incubations of the preparations with the slurry followed by centrifugations. The final samples were dialyzed against PBS, filtered with $0.22 \mu \mathrm{m}$ PVDF filters (Merck Millipore, Billerica, MA, USA) and used for ELISA assay. Each purified phage preparation or phage lysate was tested for phage concentration by determination of phage titer after serial dilution with PBS (dilutions from $10^{-1}$ to $10^{-9}$ ). Fifty microliters of each dilution was spotted on a culture plate pre-covered with susceptible bacteria, three spots for each dilution. The plate was incubated for $8-10 \mathrm{~h}$ at $37^{\circ} \mathrm{C}$ which was enough to obtain visible plaques. The plaques were counted, mean values of three spots were calculated and the phage concentration was calculated per milliliter with regard to the dilution and spot volume.

\subsection{Bacteriophages Presenting Foreign Peptides}

Bacteriophages presenting exemplary foreign antigen were prepared by competitive phage display as described previously [27]. Briefly, Ebola virus antigen from Zaire EBOV strain RWGFRSGVPPKVVNY [41-43] was used for phage display; this antigen was designed "EB1". The relevant DNA sequence (CGTTGGGGCTTTCGTAGCGGCGTTCCGCCGAAAGTTGTTAATTAT) was cloned as N-terminal fusion with the gene hoc of T4 phage to expression vector pCDF-Duet-1 (Novagen, Merck Millipore, Darmstadt, Germany). The sequence coding for EB1 antigen was fused to the hoc gene using a mutagenizing primer in PCR. Expression E. coli B834 was transformed with the constructed plasmid, tested for effective production of EB1-Hoc fusion by SDS-PAGE and immunological detection, and used as a host for phage display cultures. Phage display cultures were conducted in LB-Broth high salt (Sigma-Aldrich, Poznań, Poland) in baffled flasks with shaking at 
$37{ }^{\circ} \mathrm{C}$ until OD600 was $0.08-0.1$, induced with IPTG (final concentration: $0.05 \mathrm{mM}$ ) and incubated with shaking at $37^{\circ} \mathrm{C}$ for $1 \mathrm{~h}$. T4 phage was added to a final concentration of $10^{5} \mathrm{pfu} / \mathrm{mL}$ and incubated with shaking at $37{ }^{\circ} \mathrm{C}$ for $8 \mathrm{~h}$. Lysate was clarified by centrifugation at $4000 \mathrm{~g}$ for $3 \mathrm{~min}$, filtered with sterile $0.22 \mu \mathrm{m}$ filters and purified (as described above). Final purified phage preparations were tested for the presence of EB1 antigen on T4 capsid by ELISA assay with a standard serum specific to synthetic EB1 oligopeptide (Lipopharm, Zblewo, Poland). Phage presenting EB1 on its capsid was designed by EB1-T4 phage.

\subsection{Phage Proteins}

Phage proteins were used as bottom antigens in ELISA immunoassay. They were produced as optimized by Miernikiewicz et al. [44,45]. Briefly, proteins were expressed in E. coli B834(DE3) $\mathrm{F}^{-}$ompT hsdS $\mathrm{B}_{\mathrm{B}}\left(\mathrm{r}_{\mathrm{B}}{ }^{-} \mathrm{m}_{\mathrm{B}}{ }^{-}\right)$gal dcm met (DE3) (Novagen, Merck Millipore, Darmstadt, Germany) grown in $\mathrm{LB}$ high salt $(10 \mathrm{~g} / \mathrm{L}$ of $\mathrm{NaCl})$ (Sigma-Aldrich, Poznań, Poland). For expression of Soc and Hoc chaperone TF (from pTf16 vector, TaKaRa Bio Inc., Saint-Germain-en-Laye, France) and chaperones groES+groEL (from pGRO7 vector, TaKaRa Bio Inc., Saint-Germain-en-Laye, France) were used, respectively. Gp23* was co-expressed with gp31 chaperone of T4 phage. Gp12 was expressed from pCDF-Duet-1 with chaperone gp57 of T4 phage. Expression was induced with $0.2 \mathrm{mM}$ IPTG (phage proteins) or $3 \mathrm{mM} \mathrm{L}$-arabinose (TaKaRa chaperones) and conducted overnight at $25{ }^{\circ} \mathrm{C}$. Harvested bacteria were lysed by freeze-thawing with lysozyme in phosphate buffer with PMSF (50 mM $\mathrm{Na}_{2} \mathrm{HPO}_{4}, 300 \mathrm{mM} \mathrm{NaCl}, 1 \mathrm{mM}$ PMSF, $\mathrm{pH}$ 7.5). The soluble fraction was incubated with glutathione sorbent slurry (Glutathione Sepharose 4B, GE Healthcare Life Sciences, Warsaw, Poland), washed with phosphate buffer, and proteins were released by proteolysis with AcTev protease $(5 \mathrm{U} / \mathrm{mL}$ ) (Invitrogen, Life Technologies Corporation, Waltham, MA, USA) at $10{ }^{\circ} \mathrm{C}$; GST tags remained bound in the resin. In the case of gp12 Ni-NTA agarose was used without proteolysis. After intensive washing the protein was eluted with imidazole buffer. LPS removal from all protein preparations was done with EndoTrap Blue (Hyglos GmbH, Bernried, Germany). Gel filtration FPLC (fast protein liquid chromatography) on a Superdex 75 10/300 GL column (GE Healthcare Life Sciences, Warsaw, Poland) was applied and proteins were dialyzed against PBS and filtered through $0.22 \mu \mathrm{m}$ PVDF filters (Merck Millipore, Darmstadt, Germany). Proteins were assessed by SDS-PAGE and concentrations were determined by the Lowry chromogenic method (Thermo Scientific, Rockford, IL, USA).

\subsection{LPS Content Determination}

The endotoxin level of the purified phage preparations was assessed using EndoLISA (ELISA-based Endotoxin Detection Assay, Hyglos, Bernried, Germany), according to the manufacturer's instructions. Diluted samples or standard dilution with Binding Buffer were incubated overnight at room temperature with shaking. Subsequently, the plate was washed and Assay Reagent was added. The fluorescent signal was detected immediately by a fluorescence reader (Synergy H4 H4MLFPTAD BioTek Instruments, Winooski, VT, USA). This assay was used to determine LPS content in purified phage preparations serving as bottom antigen source in ELISA test. Phage preparation was used for ELISA when its LPS content was lower than 1 activity unit per $\mathrm{mL}$ in order to eliminate possible reaction of animal sera with residual LPS (false-positive reactivity of serum). If the LPS content was higher than 1 activity unit per $\mathrm{mL}$, additional round of purification by LPS-affinity chromatography (described above) was conducted. 


\subsection{Immunization of Mice}

C57B16/J male mice (6-16 weeks old) were used. The animals were bred in the Animal Breeding Center of the IIET, in specific pathogen free (SPF) conditions. Mice from phage-treated groups were separated from control mice. Food, water, litter, boxes and other accessories for all mice were sterilized.

Mice ( $\mathrm{N}=6$ to 8 ) received phages in drinking water to prevent micro-injuries that can be caused by a stomach probe and which result in artificial introduction of phages into the blood. Phage concentration in water was (i) the lower dose $4 \times 10^{8} \mathrm{pfu} / \mathrm{mL}$ (thus making approx. $2 \times 10^{9} \mathrm{pfu} / \mathrm{mouse}$ daily, as calculated from typical daily water uptake) or (ii) the higher dose $4 \times 10^{9} \mathrm{pfu} / \mathrm{mL}$ (thus making approx. $2 \times 10^{10} \mathrm{pfu} / \mathrm{mouse}$ daily, as calculated from typical daily water uptake). Phage preparations were applied in drinking water without any additives for neutralization of stomach acidity, but water was mixed with PBS (1:1) in order to maintain proper ionic strength of the solution and to prevent phage aggregation and precipitation. Subcutaneous treatment was done with three subsequent injections: $5 \times 10^{9} \mathrm{pfu} / \mathrm{mouse}$ on day $0,5 \times 10^{9} \mathrm{pfu} /$ mouse on day $24,2 \times 10^{9} \mathrm{pfu} /$ mouse on day 48 , antibody level was tested on day 55 . Feces and blood from the tail vein (under anesthesia, to heparinized tubes) were collected repeatedly during the experiment (i.e., the same mice were sampled for the whole experiment). Feces were collected directly from mice (not as fecal pellets in the cages), diluted in PBS and tested for phage-specific IgA by ELISA (see below), as well as used for microbiological testing: samples were quantitatively cultured on selective microbiological plates with media selective for Gram-positive bacteria: Mueller Hinton II Blood Agar (30.0\% beef infusion, $1.75 \%$ casein hydrolysate, $0.15 \%$ starch, $1.7 \%$ agar, $5.0 \%$ sheep blood, $\mathrm{pH}$ neutral), Gram-negative bacteria: MacConkey Agar (1.7\% peptone, $0.3 \%$ proteose peptone, $1 \%$ lactose, $0.15 \%$ bile salts, $0.5 \%$ sodium chloride, $0.003 \%$ neutral red, $0.0001 \%$ crystal violet, 1.35\% agar, pH 7.0-7.1) (Graso Biotech, Starogard Gdański, Poland), and for bacteriophages: Mueller Hinton II Agar (30.0\% beef infusion, $1.75 \%$ casein hydrolysate, $0.15 \%$ starch, $1.7 \%$ agar, pH neutral with E. coli B host layer) (Graso Biotech, Poland). Identification of E. coli isolated from feces was confirmed by automated mass spectrometry microbial identification system (VITEK ${ }^{\circledR} \mathrm{MS}$, Biomerieux, Durham, NC, USA). E. coli isolated from feces were tested for their sensitivity to T4 phage infection (60 colonies) by culturing of bacterial monolayers on culture plates with phage preparations spotted on the top; plaque formation was assessed. Serum for IgM and IgG testing was separated from the blood by double centrifugation $(2250 \mathrm{~g}$ and $10,000 \mathrm{~g}$ ), each time cell and platelets pellet was discarded and supernatant fraction was saved. After the second centrifugation it was used for ELISA assay. All experiments were repeated 2-4 times. One exemplary experiment of each type was presented. Each timepoint represents multiple mice, timepoints were the same for antibody testing and for microbiological testing.

\subsection{Ethics Statements}

All animal experiments were performed according to EU Directive 2010/63/EU for animal experimentations and were approved by the 1st Local Committee for Experiments with the Use of Laboratory Animals, Wroclaw, Poland (No. 64/2009 and 76/2011). The authors followed the ARRIVE (Animal Research: Reporting of in vivo Experiments) guidelines [46]. 


\subsection{Specific Antibody Level Measurement by ELISA}

A MaxiSorp flat-bottom 96-well plate (Nunc, Thermo Scientific, Poznań, Poland) was covered with purified phage preparations obtained by chromatography as described above $(100 \mu \mathrm{L}$ per well, $\left.5 \times 10^{9}-10^{10} \mathrm{pfu} / \mathrm{mL}\right)$ or proteins $(100 \mu \mathrm{L}$ per well, $10 \mu \mathrm{g} / \mathrm{mL})$ or oligopeptide EB1 (100 $\mu \mathrm{L}$ per well, $80 \mu \mathrm{g} / \mathrm{mL}$ ) sterilely, at $4{ }^{\circ} \mathrm{C}$, overnight. Plates were washed 5 times with PBS and blocked with $1 \%$ albumin for $1 \mathrm{~h}(100 \mu \mathrm{L}$ per well $)$ at room temperature. Albumin was removed and the plate was washed 5 times with PBS with $0.05 \%$ Tween 20 (Serva, Heidelberg, Germany). Serially diluted serum was applied to the wells in $100 \mu \mathrm{L}$ per well. In the case of secretory IgA detection in feces, feces were homogenized in PBS in proportion 1/10, i.e., each $0.1 \mathrm{~g}$ of feces was supplemented with PBS up to $1 \mathrm{~mL}$. and then serially diluted and applied to the wells in $100 \mu \mathrm{L}$ per well. Samples from each mice were processed separately (sera/feces were not pooled in the groups). Each sample was processed in duplicate. The plate was incubated at $37{ }^{\circ} \mathrm{C}$ for $2 \mathrm{~h}$. Plates were washed 5 times with PBS with $0.05 \%$ Tween 20 (Serva, Heidelberg, Germany). Diluted detection antibody was added in the amount of $100 \mu \mathrm{L}$ per well: peroxidase-conjugated AffiniPure goat anti-mouse IgM (Jackson ImmunoResearch Laboratories, West Grove, PA, USA) or peroxidase-conjugated AffiniPure goat anti-mouse IgG (Jackson ImmunoResearch Laboratories) or peroxidase-conjugated AffiniPure goat anti-mouse IgA (Jackson ImmunoResearch Laboratories). Detection antibody was incubated in the wells for $1 \mathrm{~h}$ at RT in the dark, removed, and the plate was washed 5 times with PBS with 0.05\% Tween 20 (Serva, Heidelberg, Germany). TMB X-Treme substrate reagent for peroxidase was used $(50 \mu \mathrm{L})$ according to the manufacturer's instructions ( $\mathrm{ImmunO}_{4}$, Westminster, MD, USA). Twenty-five microliters of $2 \mathrm{~N} \mathrm{H}_{2} \mathrm{SO}_{4}$ was added to each well without substrate removal, then absorbance was measured at $450 \mathrm{~nm}$ (main reading) and $550 \mathrm{~nm}$ (background). The background values were subtracted from the main readings and the average value of each duplicate was calculated. In the case of relative increases of antibody levels in time (Figure 1), OD values were presented. To compare immunogenicity in selected conditions, to compare individual immunogenicity of phage proteins and to assess immunization by EB1 antigen (Figures 2 and 3 Table 1), highly responsive sera from animals were used to establish a reference standard serum according to Miura et al. [24,25]. Briefly, to calculate ELISA units (EU), 10 points of standard serum dilutions were determined on each plate, and the dilution giving an optical density at $450 \mathrm{~nm}$ (OD450) of 1 was assigned as 1000 EU. A standard curve was calculated by the plate reader software (Gen5 Data Analysis Software) and fitted to a function that converted OD values to EU. Each EU value was normalized, and the average value of each duplicate (per sample) was calculated. Immunogenicity in selected conditions was assessed by fold of increase in EU (comparing immunized animals to control animals). All experiments were repeated 2-4 times; they were not summarized; exemplary experiments with their individual $\mathrm{N}$ values and statistical significance were presented. Statistical analysis was done by one-way analysis of variance (ANOVA, Tukey) or the Kruskal-Wallis test or the Mann-Whitney test with the Statistica 8.0 software package [47].

\section{Conclusions}

Phages present in the gut can induce anti-phage antibodies in blood when the exposure is long enough. The effect is also dose dependent. T4 phage (used in this study) appeared to be low immunogenic, since 
only very high doses of the phage applied for a long time elicited a significant increase in specific antibody levels. However, secretion of specific IgA, even if not readily induced, had a devastating effect on phage viability. Increase of IgA seemed to play a much more important role than selection for phage-resistant E. coli in the gut flora; phage-resistant strains occurred relatively late. Termination of phage treatment results in a gradual decrease of secretory IgA, even to insignificant levels that again allow for transition of active phage particles through the gut. Second administration of phage also induces secretory $\operatorname{IgA}$, it increases sooner than that induced by the first administration. Specific antibodies in the blood and in the gut are induced by proteins Hoc and gp12, while gp23*, gp24*, and Soc are weakly immunogenic. Foreign antigens presented on the phage can also induce antigen-specific antibodies, thus we propose T4 phage as possible platform for oral vaccines development.

\section{Acknowledgments}

We are grateful to Andrzej Górski, the head of the Bacteriophage Laboratory, IIET, for his kind help and advice during preparation of this manuscript. This work was supported by the National Science Centre in Poland, grant UMO-2012/05/E/NZ6/03314, grant NN405675940, and by the Wroclaw Centre of Biotechnology programme The Leading National Research Centre (KNOW) for years 2014-2018.

\section{Author Contributions}

K.D. conceived and designed the experiments; J.M., W.B., D.L., K.H.S., A.K., Z.K., P.M., A.P., J.C., B.O., A.K., K.W., M.H., M.M. and K.D. performed the experiments; K.D., P.M. and J.M. analyzed the data; K.D. wrote the paper.

\section{Conflicts of Interest}

The authors declare no conflict of interest.

\section{References}

1. Abedon, S.T.; Kuhl, S.J.; Blasdel, B.G.; Kutter, E.M. Phage treatment of human infections. Bacteriophage 2011, 1, 66-85. [CrossRef] [PubMed]

2. Bruttin, A.; Brüssow, H. Human volunteers receiving Escherichia coli phage T4 orally: A safety test of phage therapy. Antimicrob. Agents Chemother. 2005, 49, 2874-2878. [CrossRef] [PubMed]

3. Kutter, E.; de Vos, D.; Gvasalia, G.; Alavidze, Z.; Gogokhia, L.; Kuhl, S.; Abedon, S.T. Phage therapy in clinical practice: Treatment of human infections. Curr. Pharm. Biotechnol. 2010, 11, 69-86. [CrossRef] [PubMed]

4. Międzybrodzki, R.; Borysowski, J.; Weber-Dąbrowska, B.; Fortuna, W.; Letkiewicz, S.; Szufnarowski, K.; Pawełczyk, Z.; Rogóż, P.; Kłak, M.; Wojtasik, E.; et al. Clinical aspects of phage therapy. Adv. Virus Res. 2012, 83, 73-121. [PubMed]

5. Sarker, S.A.; McCallin, S.; Barretto, C.; Berger, B.; Pittet, A.C.; Sultana, S.; Krause, L.; Huq, S.; Bibiloni, R.; Bruttin, A.; et al. Oral T4-like phage cocktail application to healthy adult volunteers from Bangladesh. Virology 2012, 434, 222-232. [CrossRef] [PubMed] 
6. Wolska, K.; Kot, B.; Piechota, M.; Frankowska, A. Resistance of Pseudomonas aeruginosa to antibiotics. Postep. Hig. Med. Dosw. 2013, 67, 1300-1311. [CrossRef]

7. Przybylski, M.; Borysowski, J.; Jakubowska-Zahorska, R.; Weber-Dąbrowska, B.; Górski, A. T4 bacteriophage-mediated inhibition of adsorption and replication of human adenovirus in vitro. Future Microbiol. 2015, 10, 453-460. [CrossRef] [PubMed]

8. Jiang, J.; Abu-Shilbayeh, L.; Rao, V.B. Display of a PorA peptide from Neisseria meningitidis on the bacteriophage T4 capsid surface. Infect. Immun. 1997, 65, 4770-4777. [PubMed]

9. Shivachandra, S.B.; Rao, M.; Janosi, L.; Sathaliyawala, T.; Matyas, G.R.; Alving, C.R.; Leppla, S.H.; Rao, V.B. In vitro binding of anthrax protective antigen on bacteriophage T4 capsid surface through Hoc-capsid interactions: A strategy for efficient display of large full-length proteins. Virology 2006, 345, 190-198. [CrossRef] [PubMed]

10. Shivachandra, S.B.; Li, Q.; Peachman, K.K.; Matyas, G.R.; Leppa, S.H.; Alving, C.R.; Rao, M.; Rao, V.B. Multicomponent anthrax toxin display and delivery using bacteriophage T4. Vaccine 2007, 25, 1225-1235. [CrossRef] [PubMed]

11. Ren, Z.J.; Lewis, G.K.; Wingfield, P.T.; Locke, E.G.; Steven, A.C.; Black, L.W. Phage display of intact domains at high copy number: A system based on Soc, the small outer capsid protein of bacteriophage T4. Protein Sci. 1996, 5, 1833-1843. [CrossRef] [PubMed]

12. Sathaliyawala, T.; Rao, M.; Maclean, D.M.; Birx, D.L.; Alving, C.R.; Rao, V.B. Assembly of human immunodeficiency virus (HIV) antigens on bacteriophage T4: A novel in vitro approach to construct multicomponent HIV vaccines. J. Virol. 2006, 80, 7688-7698. [CrossRef] [PubMed]

13. Kamme, C. Antibodies against staphylococcal bacteriophages in human sera. I. Assay of antibodies in healthy individuals and in patients with staphylococcal infections. Acta Pathol. Microbiol. Scand. B Microbiol. Immunol. 1973, 81, 741-748. [PubMed]

14. Smith, H.W.; Huggins, M.B.; Shaw, K.M. Factors influencing the survival and multiplication of bacteriophages in calves and in their environment. J. Gen. Microbiol. 1987, 133, 1127-1135. [CrossRef] [PubMed]

15. Górski, A.; Międzybrodzki, R.; Borysowski, J.; Dąbrowska, K.; Wierzbicki, P.; Ohams, M.; Korczak-Kowalska, G.; Olszowska-Zaremba, N.; Łusiak-Szelachowska, M.; Kłak, M.; et al. Phage as a modulator of immune responses: Practical implications for phage therapy. Adv. Virus Res. 2012, 83, 41-71. [PubMed]

16. Górski, A.; Wazna, E.; Dabrowska, B.W.; Dabrowska, K.; Switała-Jeleń, K.; Miedzybrodzki, R. Bacteriophage translocation. FEMS Immunol Med. Microbiol. 2006, 46, 313-319. [CrossRef] [PubMed]

17. Łusiak-Szelachowska, M.; Zaczek, M.; Weber-Dąbrowska, B.; Międzybrodzki, R.; Kłak, M.; Fortuna, W.; Letkiewicz, S.; Rogóż, P.; Szufnarowski, K.; Jończyk-Matysiak, E.; et al. Phage neutralization by sera of patients receiving phage therapy. Viral Immunol. 2014, 27, 295-304. [CrossRef] [PubMed]

18. Dąbrowska, K.; Miernikiewicz, P.; Piotrowicz, A.; Hodyra, K.; Owczarek, B.; Lecion, D.; Kaźmierczak, Z.; Letarov, A.; Górski, A. Immunogenicity studies of proteins forming the T4 phage head surface. J. Virol. 2014, 88, 12551-12557. [CrossRef] [PubMed] 
19. Huff, W.E.; Huff, G.R.; Rath, N.C.; Donoghue, A.M. Immune interference of bacteriophage efficacy when treating colibacillosis in poultry. Poult. Sci. 2010, 89, 895-900. [CrossRef] [PubMed]

20. Reyes, A.; Semenkovich, N.P.; Whiteson, K.; Rohwer, F.; Gordon, J.I. Going viral: Next-generation sequencing applied to phage populations in the human gut. Nat. Rev. Microbiol. 2012, 10, 607-617. [CrossRef] [PubMed]

21. Reyes, A.; Wu, M.; McNulty, N.P.; Rohwer, F.L.; Gordon, J.I. Gnotobiotic mouse model of phage-bacterial host dynamics in the human gut. Proc. Natl. Acad. Sci. USA 2013, 110, 20236-20241. [CrossRef] [PubMed]

22. Dalmasso, M.; Hill, C.; Ross, R.P. Exploiting gut bacteriophages for human health. Trends Microbiol. 2014, 22, 399-405. [CrossRef] [PubMed]

23. Duerkop, B.A.; Hooper, L.V. Resident viruses and their interactions with the immune system. Nat. Immunol. 2013, 14, 654-659. [CrossRef] [PubMed]

24. Dabrowska, K.; Switała-Jelen, K.; Opolski, A.; Weber-Dabrowska, B.; Gorski, A. Bacteriophage penetration in vertebrates. J. Appl. Microbiol. 2005, 98, 7-13. [CrossRef] [PubMed]

25. Miura, K.; Orcutt, A.C.; Muratova, O.V.; Miller, L.H.; Saul, A.; Long, C.A. Development and characterization of a standardized ELISA including a reference serum on each plate to detect antibodies induced by experimental malaria vaccines. Vaccine 2008, 26, 193-200. [CrossRef] [PubMed]

26. Miura, K.; Takashima, E.; Deng, B.; Tullo, G.; Diouf, A.; Moretz, S.E.; Nikolaeva, D.; Diakite, M.; Fairhurst, R.M.; Fay, M.P.; et al. Functional comparison of Plasmodium falciparum transmission-blocking vaccine candidates by the standard membrane-feeding assay. Infect. Immun. 2013, 81, 4377-4382. [CrossRef] [PubMed]

27. Ceglarek, I.; Piotrowicz, A.; Lecion, D.; Miernikiewicz, P.; Owczarek, B.; Hodyra, K.; Harhala, M.; Górski, A.; Dąbrowska, K. A novel approach for separating bacteriophages from other bacteriophages using affinity chromatography and phage display. Sci. Rep. 2013, 3, 3220. [CrossRef] [PubMed]

28. Weber-Dabrowska, B.; Dabrowski, M.; Slopek, S. Studies on bacteriophage penetration in patients subjected to phage therapy. Arch. Immunol. Ther. Exp. 1987, 35, 563-568.

29. Keller, R.; Engley, F.B. Fate of bacteriophage particles introduced into mice by various routes. Proc. Soc. Exp. Biol. Med. 1958, 98, 577-579. [CrossRef] [PubMed]

30. Hoffmann, M. Animal experiments on the mucosal passage and absorption viremia of T3 phages after oral, tracheal and rectal administration. Zentralbl. Bacteriol. Orig. 1965, 198, 371-390.

31. Fogelman, I.; Davey, V.; Ochs, H.D.; Elashoff, M.; Feinberg, M.B.; Mican, J.; Siegel, J.P.; Sneller, M.; Lane, H.C. Evaluation of CD4 T cell function in vivo in HIV-infected patients as measured by bacteriophage phiX174 immunization. J. Infect. Dis. 2000, 182, 435-441. [CrossRef] [PubMed]

32. Merril, C.R.; Biswas, B.; Carlton, R.M.; Jensen, N.C.; Creed, G.J.; Zullo, S.; Adhya, S. Long-circulating bacteriophage as antibacterial agents. Proc. Natl. Acad. Sci. USA 1996, 93, 3188-3192. [CrossRef] [PubMed] 
33. Geier, M.R.; Trigg, M.E.; Merril, C.R. Fate of bacteriophage lambda in non-immune germ-free mice. Nature 1973, 246, 221-223. [CrossRef] [PubMed]

34. Borysowski, J.; Górski, A. Is phage therapy acceptable in the immunocompromised host? Int. J. Infect. Dis. 2008, 12, 466-471. [CrossRef] [PubMed]

35. Mordenti, J.; Chen, S.A.; Moore, J.A.; Ferraiolo, B.L.; Green, J.D. Interspecies scaling of clearance and volume of distribution data for five therapeutic proteins. Pharm Res. 1991, 8, 1351-1359. [CrossRef] [PubMed]

36. Sulakvelidze, A.; Alavidze, Z.; Morris, J.G., Jr. Bacteriophage therapy. Antimicrob. Agents Chemother. 2001, 45, 649-659. [CrossRef] [PubMed]

37. Maura, D.; Debarbieux, L. On the interactions between virulent bacteriophages and bacteria in the gut. Bacteriophage 2012, 2, 229-233. [CrossRef] [PubMed]

38. Weiss, M.; Denou, E.; Bruttin, A.; Serra-Moreno, R.; Dillmann, M.L.; Brüssow, H. In vivo replication of T4 and T7 bacteriophages in germ-free mice colonized with Escherichia coli. Virology 2009, 393, 16-23. [CrossRef] [PubMed]

39. Clark, J.R.; March, J.B. Bacteriophages and biotechnology: Vaccines, gene therapy and antibacterials. Trends Biotechnol. 2006, 24, 212-218. [CrossRef] [PubMed]

40. Clark, J.R.; March, J.B. Bacteriophage mediated nucleic acid immunisation. FEMS Immunol. Med. Microbiol. 2004, 40, 21-26. [CrossRef]

41. Xu, L.; Sanchez, A.; Yang, Z.; Zaki, S.R.; Nabel, E.G.; Nichol, S.T.; Nabel, G.J. Immunization for Ebola virus infection. Nat. Med. 1998, 4, 37-42. [CrossRef] [PubMed]

42. Shedlock, D.J.; Aviles, J.; Talbott, K.T.; Wong, G.; Wu, S.J.; Villarreal, D.O.; Myles, D.J.; Croyle, M.A.; Yan, J.; Kobinger, G.P.; et al. Induction of broad cytotoxic T cells by protective DNA vaccination against Marburg and Ebola. Mol. Ther. 2013, 21, 1432-1444. [CrossRef] [PubMed]

43. Becquart, P.; Mahlakõiv, T.; Nkoghe, D.; Leroy, E.M. Identification of continuous human B-cell epitopes in the VP35, VP40, nucleoprotein and glycoprotein of Ebola virus. PLoS ONE 2014, 9, e96360. [CrossRef] [PubMed]

44. Miernikiewicz, P.; Owczarek, B.; Piotrowicz, A.; Boczkowska, B.; Rzewucka, K.; Figura, G.; Letarov, A.; Kulikov, E.; Kopciuch, A.; Świtała-Jeleń, K.; et al. Recombinant expression and purification of T4 phage Hoc, Soc, gp23, gp24 proteins in native conformations with stability studies. PLoS ONE 2012, 7, e38902. [CrossRef] [PubMed]

45. Miernikiewicz, P.; Institute of Immunology and Experimental Therapy, Polish Academy of Sciences, Wrocław, Poland. Personal Communication, 2013.

46. Kilkenny, C.; Browne, W.J.; Cuthill, I.C.; Emerson, M.; Altman, D.G. Improving bioscience research reporting: The ARRIVE guidelines for reporting animal research. PLoS Biol. 2010, 8, e1000412. [CrossRef] [PubMed]

47. StatSoft, Inc. STATISTICA (data analysis software system), version 8.0. Available online: http://www.statsoft.com (accessed on 20 April 2015).

(C) 2015 by the authors; licensee MDPI, Basel, Switzerland. This article is an open access article distributed under the terms and conditions of the Creative Commons Attribution license (http://creativecommons.org/licenses/by/4.0/). 